\title{
STRUCTURAL CHANGES MANIFESTED BY SERTOLI CELLS DURING EXPERIMENTAL ALLERGIC ORCHITIS IN GUINEA-PIGS
}

\author{
A. L. KIERSZENBAUM* AND R. E. MANCINI \\ Centro de Investigaciones sobre Reproducción, Facultad de Medicina, \\ Universidad de Buenos Aires, Argentina
}

(Received 4th September 1972)

Experimental allergic orchitis is an organ-specific disorder, which is immunologically mediated, but interpretations of histopathological and immunological studies of the temporal sequence of events leading to aspermatogenesis still remain controversial. Some authors have held that degeneration of germinal cells of the testis is the predominant change which results in aspermatogenesis (Freund, Lipton \& Thompson, 1953; Freund, Thompson \& Lipton, 1955). On the other hand, destruction of the germinal epithelium has been described following the appearance of early mononuclear infiltrates in the intertubular space with direct invasion of the seminiferous tubules (Waksman, 1959), and the route of sperm passage through the rete testis, the ductulis efferentes and the caput epididymidis (Brown, Glynn \& Holborow, 1963; Brown \& Glynn, 1969; Johnson, 1970). Tung, Unanue \& Dixon (1970) postulated that mononuclear cells can break through the basement membrane and penetrate into the seminiferous tubules. Infarction, oedema and ischaemia have all been causally related to damage of the germinal epithelium (Levine \& Sowinski, 1970). Since little attention has been paid to detailed analysis of different cell types occurring during germinal epithelium damage, and since there has been increasing interest in studies dealing with the Sertoli cell, we undertook an investigation of the sequence of morphological changes manifested by the Sertoli cells during experimental allergic orchitis.

In this study, sixty, healthy, non-inbred, adult male guinea-pigs weighing 400 to $500 \mathrm{~g}$ were divided into four groups. Group 1 consisted of twenty-four animals each sensitized by a dorsal intracutaneous injection of a single dose of the antigen (homologous testicular homogenate mixed with complete Freund's adjuvant). Control Groups 2 and 3 (twelve animals each) were respectively injected with testicular homogenate or with adjuvant alone in doses similar to those administered to the experimental Group 1. Group 4 consisted of twelve normal intact animals also used as controls. After sensitization, two to four of the animals from each group were killed weekly until the 6th week. Blood samples were taken for immunoserological studies. Tests for complement fixation and for antibodies producing passive cutaneous anaphylaxis were performed; the results have already been published (Mancini, Huidobro, Fernandez

* Present address: Laboratories for Reproductive Biology, University of North Garolina, Chapel Hill, North Garolina, 27514, U.S.A. 
Collazo \& Monastirsky, 1966). In all cases, an equatorial segment of both gonads and the entire epididymis were fixed in Bouin's and Cleland's fluids, embedded in paraffin wax, sectioned and stained by the periodic acid-Schiff method and haematoxylin. For electron microscopy, small pieces of testicular tissue were fixed in $2.5 \%$ glutaraldehyde in $0.2 \mathrm{M}$-phosphate buffer, be ${ }^{f}$ re being post-fixed with $1 \%$ osmium tetroxide in veronal-acetate buffer, dehydrated in graded alcohols and embedded in Maraglas. Silver-grey sections (50 to $70 \mu \mathrm{m}$ thick) were stained with uranyl acetate and lead citrate and examined in a Siemens Elmiskop I EM.

In comparison to the control groups of animals, the immunized guinea-pigs exhibited several events in the following order. At the end of the 1st week, moderate congestion and oedema in some intertubular areas appeared coincidentally with a progressive vesiculation in the cytoplasm of the Sertoli cells (Pl. 1, Fig. 1), especially in the neighbouring seminiferous tubules. At the ultrastructural level, dilatation and vesiculation of the smooth endoplasmic reticulum in focal cytoplasmic areas of Sertoli cells were evident (Pl. 1, Fig. 4). During the 2nd and 3rd weeks, vesiculation of Sertoli cells had considerably increased ( $\mathrm{Pl}$. 1 , Figs 2 and 3). At the same time, sloughing of germinal cells with clear signs of cytolysis was observed in an appreciable number of tubules beginning with all types of spermatids and followed by spermatocytes. Some of these cells showed eosinophilic cytoplasm and/or pycnotic nuclei. PAS-positive acrosomes were detached from spermatids and masses of fused acrosomes were also seen near the sloughed cells, inside the Sertoli cell cytoplasm, or free in the lumen. The retention of essentially normal structure by the neighbouring germinal cells during the 1 st week was in striking contrast to the alteration of Sertoli cells (Pl. 1, Fig. 4 ). From the 2nd week onward, when spermatocytes and spermatids were affected by the degenerative process, the Sertoli cells appeared to be engaged in the phagocytosis of these cells as shown by the presence of either engulfed cells or cell fragments (PI. 2, Fig. 5). This enhanced phagocytic activity was closely associated with the accumulation of numerous dense bodies, lipid droplets, and different types of lysosomes. No ostensible changes could be observed in mitochondria, Golgi apparatus, or in other intercisternal areas of Sertoli cells. Although nuclear pycnosis and/or cytolysis were common occurrences in

\section{EXPLANATION OF PLATE 1}

FIG. 1. Part of the seminiferous tubule of a guinea-pig 1 week after sensitization, showing incipient vesiculation in the cytoplasm of a Sertoli cell (arrows). PAS-haematoxylin. $\times 650$.

Fig. 2. Part of the seminiferous tubule of a guinea-pig 2 weeks after sensitization, showing advanced vesiculation of a Sertoli cell (arrows) and the beginning of sloughing of spermatids and spermatocytes. PAS-haematoxylin. $\times 650$.

FIG. 3. Part of the seminiferous tubule of a guinea-pig 4 weeks after sensitization, showing more advanced vesiculation of a Sertoli cell (arrows) and complete sloughing of spermatocytes and spermatids, which give signs of cytolysis. Some spermatogonia are seen at the tubular wall with apparently normal features but some others have pycnotic nuclei. PAS-haematoxylin. $\times 650$.

Fig. 4. A spermatogonium (Sp) and Sertoli cell (S) closely associated with the tubular wall, the cytoplasm of the Sertoli cell showing focal dilatation of smooth endoplasmic reticulum cisternae in contrast with the unchanged state of the spermatogonia. bm $=$ basement membrane. $\times 9000$. 
PLATE 1

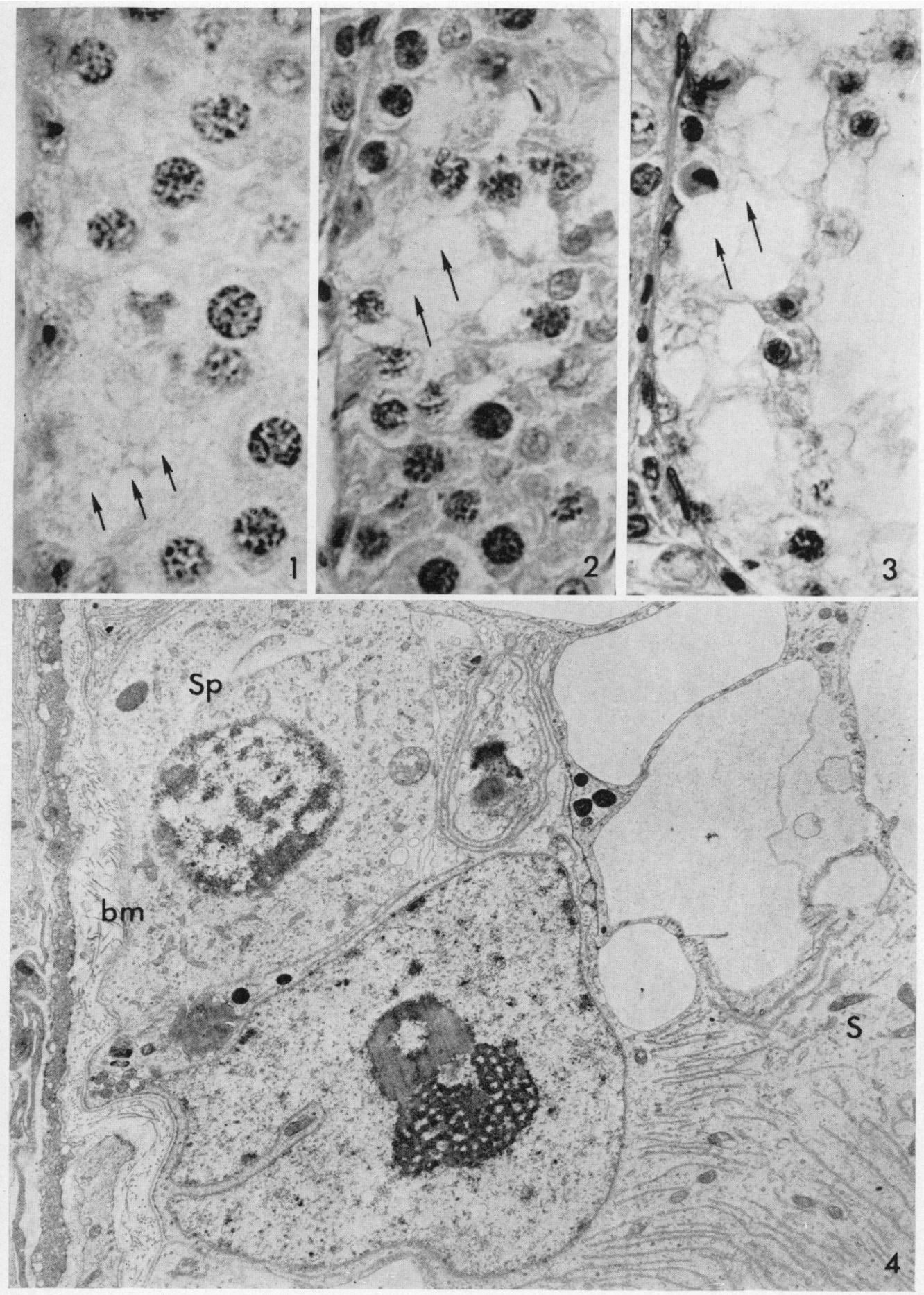

(Facing p. 120) 
PLATE 2

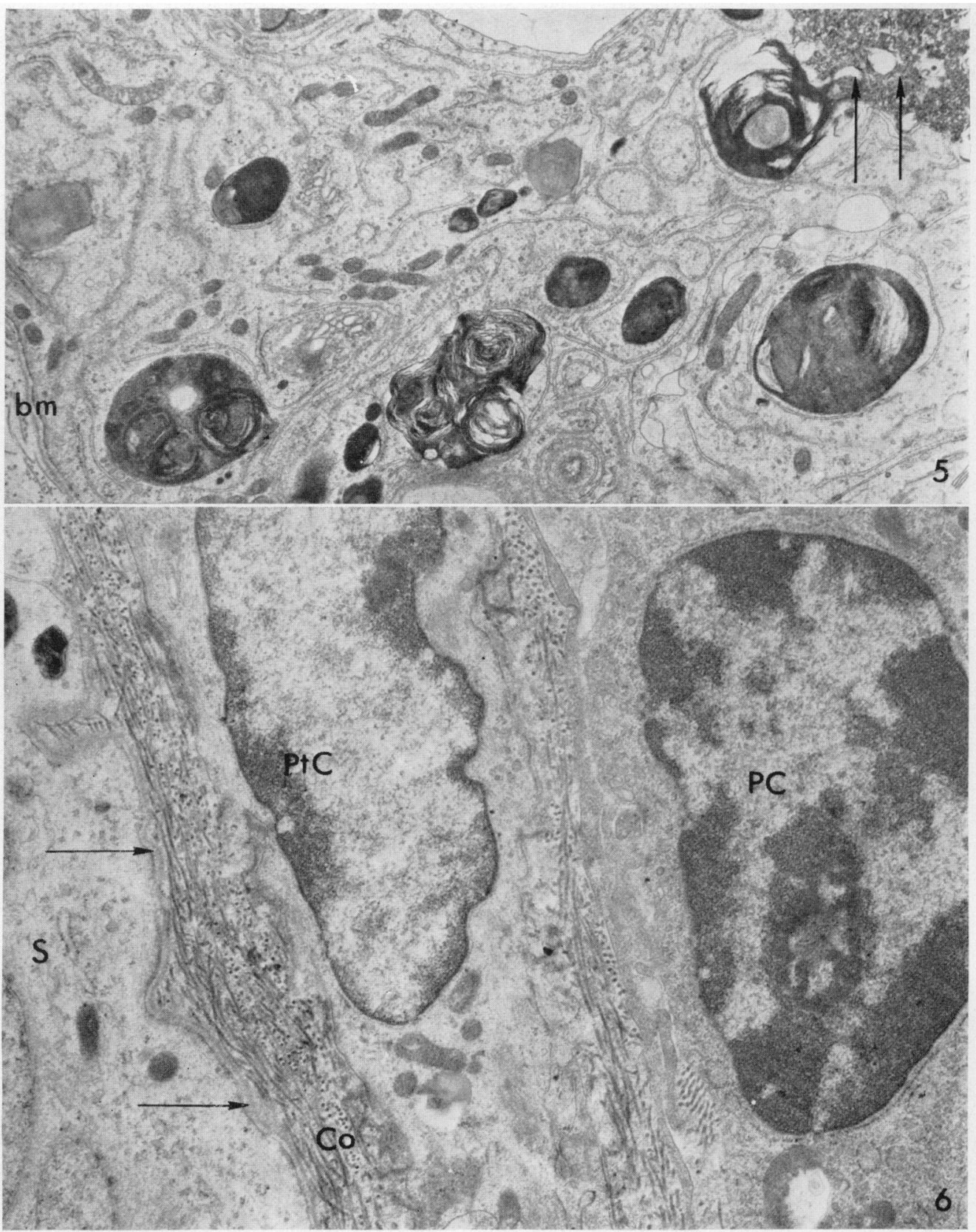

(Facing p. 121) 
germinal cells, other changes taking place in immature spermatids were indicated by the presence of coarse clumps of chromatin and accumulations of a granular material in the nucleoplasm, possibly corresponding to interchromatin granules.

In the intertubular spaces, there was an increase in the perivascular infiltration of mononuclear cells intermingled with scattered polymorphonuclear neutrophils, and some medium and small arterioles showed hyperplastic and hypertrophic endothelium. The inner portion of the seminiferous tubular wall adjacent to Sertoli cells was not seen in intimate contact with inflammatory cells, neither was the transit of those cells into the seminiferous tubles through defects in the basal lamina observed, though the occasional presence of plasma cells close to the tubular wall was noted (PI. 2, Fig. 6). The ultrastructural feature of the basement membrane, subjacent network of collagen fibrils, and layers of peritubular cells disclosed no ostensible modifications in the presence of extensive perivascular cell infiltration.

From the 4th to the 6th week, the majority of the seminiferous tubules appeared devoid of germinal cells. Some of them still had a few spermatogonial cells showing apparently normal ultrastructural features. Sertoli cells exhibiting intact nuclei and nucleoli displayed a hypertrophied cytoplasm filled with large vacuoles. In the intertubular spaces, mononuclear cells were still identifiable, though reduced in number.

It can be concluded that at least in the early stages following immunization, dilatation and vesiculation, particularly of smooth endoplasmic reticulum, was a constant pathological response in Sertoli cells, and preceded cytolysis and sloughing of the germinal cells. This phenomenon was accompanied by vascular changes in the intertubular spaces which coincided, as previously reported(Mancini et al., 1966), with the appearance of a bradikinin-like substance. When one considers the rôle of Sertoli cells in the sloughing and cytolysis of the germinal cells, one must take into account that all these cells, except spermatogonia, are normally included in the cytoplasm of the Sertoli cell. The concept of the sustentacular and nutritional function of this cell was recently reinforced by experiments demonstrating that the intratubular passage of a variety of circulating substances, including proteins, may take place through the cytoplasm and intercellular spaces which separate this cell from the germinal cells (Mancini, Vilar, Alvarez \& Seiguer, 1965; Fawcett, Leak \& Heidger, 1970). It is possible to conceive that antispermatic antibodies, whether circulating and/or mononuclear cell-mediated (Voisin \& Toullet, 1968), might gain access to interact with antigenic germinal cells by way of the cytoplasm of the Sertoli cells or through the intercellular spaces. Thus, the reaction pattern described above, namely distension of the lumen of endoplasmic reticulum cisternae and their conversion in

\section{EXPLANATION OF PLATE 2}

FIG. 5. Cytoplasmic area of a Sertoli cell during phagocytic activity showing dense bodies, lipid droplets and lysosomes. The arrows point to a lysosome closely associated with débris of a phagocytosed cell. $\mathrm{bm}=$ basement membrane. $\times 22,000$.

Fig. 6. A plasma cell (PC) is shown in close contact with collagen fibres $(\mathrm{Co})$ and with a peritubular cell $(\mathrm{PtC})$. The unchanged state of the different components of the seminiferous tubular wall, especially the basement membrane (arrows), can be observed. $\mathrm{S}=$ Sertoli cell. $\times 26,000$. 
vesicles, may reflect an earlier response of Sertoli cells to the immunologically mediated injury directed against germinal target cells. All these interpretations appear supported by the fact that labelled antispermatic antibodies react with the acrosome of spermatids and spermatozoa and not with Sertoli cell cytoplasm (Voisin \& Toullet, 1968; Mancini, Monastirsky, Fernandez Collazo, Seiguer \& Alonso, 1969). It should be noted that such a reaction is also present in the Sertoli cells of animals treated with cytotoxic drugs (Kierszenbaum, 1970) or exposed to X-irradiation (Vilar, 1971). This, in turn, supports the concept that dilatation and vesiculation of endoplasmic reticulum constitute a nonspecific response to a variety of injurious stimuli (Goldblatt, 1972). It is probable that progressive vesiculation which extends in close aposition to the plasma membrane may induce a structural and functional impairment in the Sertoligerminal cell relationship with subsequent detachment of the latter cells. This detachment might be facilitated by the marginal vacuoles and not by a direct disruption of the intercellular bindings. At the same time, a direct interaction between the antibodies and the germinal cells would take place, and cytolysis with subsequent aspermatogenesis would develop.

This investigation was supported by a grant from The Population Council, Inc., New York, U.S.A.

\section{REFERENCES}

Brown, P. C. \& Glynn, L. E. (1969) The early lesion of experimental allergic orchitis in guinea-pigs: an immunological correlation. F. Path. Bact. 98, 277.

Brown, P. C., GlynN, L. E. \& Holborow, E. J. (1963) The pathogenesis of experimental allergic orchitis in guinea pigs. 7. Path. Bact. 86, 505.

FAwcett, D. W., Leak, L. V. \& Heidger, P. M., JR (1970) Electron microscopic observations on the structural components of the blood-testis barrier. 7. Reprod. Fert. Suppl. 10, 105.

Freund J., Lipton, M. M. \& Thompson, G. E. (1953) Aspermatogenesis in the guinea pig induced by testicular tissue and adjuvants. F. exp. Med. 97, 711.

Freund, J., ThOMPson, G. E. \& Lipton, M. M. (1955) Aspermatogenesis, anaphylaxis and cutaneous sensitization induced in the guinea pig by homologous testicular extract. F. exp. Med. 101, 591.

Goldblatt, P. J. (1972) Molecular pathology of the endoplasmic reticulum. Sub-cell. Biochem. 1, 147.

Johnson, M. H. (1970) Changes in the blood-testis barrier of the guinea-pig in relation to histopathological damage following iso-immunization with testis. F. Reprod. Fert. 22, 119.

Kierszennaum, A. L. (1970) Effect of Trenimon on the ultrastructure of Sertoli cells in the mouse. Virchows Arch. Abt. B: Zell Path. 5, 1.

Levine, S. \& Sowinski, R. (1970) Allergic inflammation, infarction and induced localization in the testis. Am. F. Path. 59, 437.

Mancini, R. E., Huidobro, H., Fernandez Collazo, E. R. \& Monastirsky, R. (1966) Detection of a kinin substance in the testis of guinea pig after induced allergic orchitis. Proc. Soc. exp. Biol. Med. 123, 227.

Mancini, R. E., Monastirsky, R., Fernandez Collazo, E., Seiguer, A. C. \& Alonso, A. (1969) Cytotoxic action of antispermatic antibodies on guinea pig germinal cells in vitro. Fert. Steril. 20,779 .

Mancini, R. E., Vilar, O., Alvarez, B. \& Seiguer, A. C. (1965) Extravascular and intratubular diffusion of labeled serum proteins in the rat testis. 7. Histochem. Cytochem. 13, 376.

Tung, K. S. K., Unanue, E. R. \& Dixon, F. J. (1970) The immunopathology of experimental allergic orchitis. Am. F. Path. 60, 313.

VILAR, O. (1971) Efecto de las radiaciones ionizantes sobre el testículo humano. In: Progresos en Endocrinología, p. 78. Eds. L. Cardonet and L. Lencioni. Editorial Panamericana, Buenos Aires.

Vorsin, G. A. \& Toullet, F. (1968) Etude sur l'orchite aspermatogenique autoimmune et les autoantigènes des spermatozoïdes chez le cobaye. Annls Inst. Pasteur, Paris, 114, 727.

Waksman, B. H. (1959) A histologic study of the auto-allergic testis lesion in the guinea pig. J. exp. Med. 109,311 . 